\title{
SERGANČIŲJŲ ARTERINE HIPERTENZIJA GYVENIMO KOKYBĖS SĄSAJOS SU LIGOS SUVOKIMU IR ŽINIOMIS APIE JĄ
}

\author{
Jonas Sąlyga ${ }^{2,3}$, Gintarẻ Šakalytė ${ }^{1}$, Laimutė Kazlauskienè $\dot{2}^{2,3}$, \\ Vaida Motužyte்2, Geriuldas Žiliukas ${ }^{2,3}$ \\ ${ }^{1}$ Lietuvos sveikatos mokslu universitetas, ${ }^{2}$ Klaipèdos universitetas, ${ }^{3}$ Klaipédos Jürininku ligoninè
}

Raktažodžiai: arterinè hipertenzija, gyvenimo kokybè, suvokimas, žinios apie ligą.

\begin{abstract}
Santrauka
Tikslas - išanalizuoti sergančiųų arterine hipertenzija su sveikata susijusios gyvenimo kokybès sąsajas su ligos suvokimu ir žiniomis apie ją.

Metodika. Naudota apklausos anketa sudaryta iš 3 klausimynų: Arterinės hipertenzijos žinių lygio skalė; Ligos suvokimo klausimynas; Su sveikata susijusios gyvenimo kokybės klausimynas. Imtị sudare 389 respondentai - 180 vyrų, 209 moterys. Duomenų analizè atlikta statistinių programu paketu SPSS 17.0.1 for Windows. Tyrimas atliktas laikantis etikos principų.

Rezultatai. Nustatyta, kad tiriamieji gerai suvokè ligos kontrolę ir jos riziką sveikatai. Moterų žinios buvo reikšmingai $(p<0,001)$ geresnès, nei vyrų. Gyvenimo kokybę neigiamai veikia ligos keliami sunkumai, teigiamai - geresnis ligos kontrolès būtinumo suvokimas. Visose gyvenimo kokybės srityse, susijusiose su fizine sveikata ir energingumu (gyvybingumu), geresni vertinimai susiję su geresnemis žiniomis apie arterinę hipertenziją.

Išvada. Žinios ir suvokimas apie ligą skirtingai veikia su sveikata susijusią gyvenimo kokybę. Pacientai, turintys daugiau žinių apie ligą, geriau vertina su sveikata susijusią gyvenimo kokybę, o turintys geresnį suvokimą apie ligą - blogiau.
\end{abstract}

\section{Ivadas}

Arterine hipertenzija (AH) - liga, pasireiškianti padidèjusiu arteriniu kraujospūdžiu (AKS), paveikianti širdies ir kraujagyslių struktūrą, negydant progresuojanti. AH priskiriama prie aukščiausio lygio rizikos veiksnių, lemiančių ligos komplikacijas, neiggalumą, ankstyvą mirtį. Išsivysčiusiose šalyse AH diagnozuojama 15-37 proc. suaugusių gyventojų, Jungtinėse Amerikos Valstijose (JAV) - 27 proc., Rytų Europos šalyse, įskaitant ir Lietuvą, du kartus dažniau [6].
Lietuvoje sergamumas AH didesnis, nei kitose išsivysčiusiose Europos ar pasaulio šalyse. Vis dar trūksta duomenų apie sergančiųų AH požiūrị i ligą, jų motyvaciją optimaliam ligos gydymui, savo būklès kitimo vertinimui. Šią situaciją lemia nepakankamas pacientų informavimas apie ligą bei informacijos trūkumas [13].

Pasaulyje $[1,3-5,7,9,16,17]$ ir Lietuvoje $[8,10,13]$ atliktuose tyrimuose aptariami AH sukeliantys veiksniai, jų paplitimas tarp sergančiujų $\mathrm{AH}$, sąsajos su socialiniu pacientų statusu, tačiau trūksta moksliškai pagrịstų duomenų apie pacientų žinių ir ligos suvokimo įtaką sveikatai. Tikslingai suteikta informacija gali lemti pacientų motyvaciją gydytis, padèti pagerinti jų gyvenimo kokybę, atitolinti ar išvengti ligos komplikacijų. Tyrimų, kurie padètu ịvertinti sveikatos priežiūros specialistų (SPS) ir pacientų, sergančiųų AH, bendradarbiavimo nuoseklumą ir kokybiškumą bei leistų nustatyti ir ịvertinti SPS indèli i pacientų informuotumo procesą, Lietuvoje nepakanka. Užsienio autorių atliktuose tyrimuose $[1,4,7,9,16,17]$ didelis dèmesys skiriamas $\mathrm{AH}$ gydymo efektyvumo ir gyvenimo kokybės vertinimui, tačiau su sveikata susijusios gyvenimo kokybès sąsajos su pacientų ligos suvokimu ir žiniomis apie ją tiriamos retai. Atsižvelgiant i tai, keliami probleminiai klausimai: kaip pacientai, sergantys AH, suvokia savo ligą? Kokios informacijos jiems trūksta? Kokị poveikị gyvenimo kokybei daro jų turimos žinios ir ligos suvokimas? Kaip pagerinti sergančiųų AH gyvenimo kokybę? Mūsų tyrimu siekiama išanalizuoti pacientų suvokimą ir žinias apie ligą. İvertinti sąsajas tarp žinių lygio, ligos suvokimo ir su sveikata susijusios gyvenimo kokybès.

Tyrimo tikslas - išanalizuoti sergančiujų arterine hipertenzija su sveikata susijusios gyvenimo kokybės sąsajas su ligos suvokimu ir žiniomis apie ją.

\section{Tyrimo medžiaga ir metodai}

Tyrime dalyvavo 389 AH sergantys pacientai, nuo 23 iki 88 metų. Iš jų 180 (46,3 proc) buvo vyrai ir $209(53,7$ proc.) - moterys. Dauguma ( 71,0 proc.) tiriamujų gyveno 
su partneriu(-e). AH 1- 5 metus sirgo 39,5 proc., 6-10 metu $-33,4$ proc., daugiau nei 10 metu $-17,2$ proc., 1 metus ir mažiau - 9,8 proc. tiriamujjų. Bendroje tiriamujjų grupejje kūno masès indekso (KMI) rodiklis kito nuo $16,46 \mathrm{iki} 43,87 \mathrm{~kg} / \mathrm{m}^{2}$. Nutukusieji, kurių KMI $>30 \mathrm{~kg} / \mathrm{m}^{2}$, sudare 18,7 procento. Atliktas anketinis tyrimas. Naudota Arterinès hipertenzijos žinių lygio skale (angl. Hypertension knowledge-level scale), autorius S. Erkoc [2], ị lietuvių kalbą išvertė J. Zavedskaitė [15]; Ligos suvokimo klausimynas, autorè O. Zamalijeva [14]; Su sveikata susijusios gyvenimo kokybės klausimynas (angl. Short form 36 medical outcomes study questionnaire, sutr. SF-36), ị lietuvių kalbą išvertè M. Staniūtè [11]. Gauti autorių leidimai. Duomenų analizei naudotas statistinis programu paketas SPSS 17.0.1 for Windows. Tikrintas intervalinių kintamujų pasiskirstymas pagal normalųji dèsnį, naudojant Kolmogorov-Smirnov testą ir ịvertinant asimetrijos bei eksceso koeficientų dydžius. Skirstinys laikytinas normaliu, jei koeficientai gaunami tarp -2 ir +2 . Duomenys pateikti esant normaliam pasiskirstymui vidurkis \pm standartinis nuokrypis (SD), nesant normalaus pasiskirstymo ir ranginiams kintamiesiems - vidurkis (mediana). Dviejų nepriklausomų grupių požymių, turinčių normalųji pasiskirstymą, vidurkių palyginimui naudotas neporinis Student kriterijus (t), neturintiems ir ranginiams - Mann-Whitney (U) testas. Analizuojant požymių tarpusavio ryšius, priklausomai nuo jų pasiskirstymo ir tipo, naudoti Pearson (r) ir Spearman $\left(\mathrm{r}_{\mathrm{s}}\right)$ koreliacijos metodai. Siekiant nustatyti su sveikata susijusią gyvenimo kokybę lemiančius veiksnius, atlikta daugiamatès tiesinės regresijos analizè. Naudoti statistinių hipotezių reikšmingumo lygmenys: kai p $<0,05\left(^{*}\right)$ - reikšmingas, kai $\mathrm{p}<0,01(* *)$ labai reikšmingas, kai $\mathrm{p}<0,001(* * *)$ - itin reikšmingas ir p $>0,05$ (ns) - statistiškai nereikšmingas. Tyrimas atliktas laikantis etikos principų.

\section{Tyrimo rezultatai ir jų aptarimas}

Sergančiųjų AH ligos suvokimas. Nustatyta, kad tiriamieji bendroje grupejje gerai suvokè ligos kontrolę ir jos riziką sveikatai. Moterys ligos kontrolę vertino geriau, nei vyrai. Ligos keliamus sunkumus vertino vidutiniškai. Liga

1 lentelè. Tiriamujų amžiaus, kūno masès ir AH trukmès ịtaka ligos suvokimui

KMI - kūno masès indeksas, $r$-taikytas Pearson metodas, $r_{s}$-taikytas Spearman metodas, $n$ s - statistiškai nereikšmingas ryšys

\begin{tabular}{|l|c|c|c|c|c|c|}
\hline \multirow{2}{*}{ Skalès } & \multicolumn{2}{|c|}{ Amžius } & \multicolumn{2}{c|}{ KMI } & \multicolumn{2}{c|}{ AH trukme் } \\
\cline { 2 - 7 } & $\mathbf{r}$ & $\mathbf{p}$ & $\mathbf{r}$ & $\mathbf{p}$ & $\mathbf{r}_{\mathrm{s}}$ & $\mathbf{p}$ \\
\hline Ligos rizika sveikatai & 0,19 & $<0,001$ & 0,15 & 0,003 & 0,25 & $<0,001$ \\
\hline $\begin{array}{l}\text { Ligos keliami } \\
\text { sunkumai }\end{array}$ & 0,25 & $<0,001$ & 0,07 & $\mathrm{~ns}$ & 0,26 & $<0,001$ \\
\hline Ligos kontrole & 0,03 & $\mathrm{~ns}$ & 0,03 & $\mathrm{~ns}$ & 0,01 & $\mathrm{~ns}$ \\
\hline
\end{tabular}

kèlè mažiau sunkumų poroje gyvenantiems $(\mathrm{p}<0,001)$, nei gyvenantiems po vieną tiriamiesiems.

Nustatyta, kad AH keliamos rizikos sveikatai suvokimas koreliuoja su tiriamujų amžiumi, kūno masès indeksu ir AH trukme. Vyresnio amžiaus, ilgesnès AH trukmès ir turintys didesnį KMI tiriamieji geriau suvokẻ ligos keliamą riziką sveikatai nei jaunesni, trumpiau sergantys ir turintys mažesni KMI. Ligos keliamų sunkumų vertinimui reikšmingos įtakos turèjo tiriamujų amžius ir AH trukmè - vyresnio amžiaus ir ilgiau sergančiujų šis rodiklis buvo didesnis, nei jaunesnių ir trumpiau AH sergančių tiriamujų. Ligos kontrolès vertinimui tiriamujų amžius, KMI ir ligos trukmė reikšmingos įtakos neturèjo (1 lentelè).

Sergančiųjų AH žinios apie ligą. Tiriamieji žinias apie AH ligą vertino gerai. Kitu autorių $[12,15]$ tyrimuose - vidutiniškai. Moterų žinios apie ligą, jos komplikacijas, medicinini gydymą bei medikamentų vartojimą buvo geresnès, nei vyrų (2 lentelè).

Vienų ir poroje gyvenančių tiriamųjų žinios apie AH reikšmingai nesiskyrè. Apie AKS ir AH reikšmę sveikatai geriau išmané poroje gyvenantys ir ilgiau sergantys $\mathrm{AH}$, apie gyvenimo būdą - trumpiau AH liga sergantys tiriamieji. Žinioms apie AH tiriamujų amžius ir KMI reikšmingos įtakos neturèjo.

Sergančiųjų AH su sveikata susijusi gyvenimo kokybė. Nustatyti reikšmingi $(p<0,05)$ bendro sveikatos vertinimo (BSV) ir veiklos apribojimo dèl emocinių problemų (VEP) vertinimo skirtumai pagal lytị. Moterys prasčiau vertino savo sveikatą, jų veikla buvo labiau ribota dèl emocinių problemų, nei vyrų (1 pav.).

Rezultatai parodè, kad tiriamieji, gyvenantys be partnerio, žymiai prasčiau vertino savo gyvenimo kokybę, nei gyvenantys poroje, kurie buvo fiziškai aktyvesni, jų veikla mažiau ribota dèl fizinių ir emocinių problemų (VEP) bei

2 lentelè. Žinių apie AH vertinimas pagal lytị a-vidurkis(mediana), taikytas Mann-Withney testas

\begin{tabular}{|c|c|c|c|c|}
\hline \multirow{2}{*}{ Skalës } & Vyrai & Moterys & \multirow{2}{*}{$t / U$} & \multirow{2}{*}{$\mathbf{p}$} \\
\hline & $n=180$ & $\mathrm{n}=\mathbf{2 0 9}$ & & \\
\hline $\begin{array}{l}\text { AKS ir AH } \\
\text { apibrèžimas }^{\mathrm{a}}\end{array}$ & $1,83(2)$ & $1,88(2)$ & 18339,0 & 0,451 \\
\hline $\begin{array}{l}\text { Medicininis } \\
\text { gydymas }\end{array}$ & $2,52 \pm 0,98$ & $2,76 \pm 0,76$ & $-2,70$ & 0,007 \\
\hline $\begin{array}{l}\text { Medikamentų } \\
\text { vartojimas }\end{array}$ & $3,02 \pm 1,19$ & $3,30 \pm 0,99$ & $-2,58$ & 0,010 \\
\hline Gyvenimo būdas & $3,89 \pm 1,06$ & $4,09 \pm 1,05$ & $-1,84$ & 0,067 \\
\hline Dieta & $1,57 \pm 0,62$ & $1,66 \pm 0,59$ & $-1,52$ & 0,129 \\
\hline Komplikacijos & $3,27 \pm 1,77$ & $3,85 \pm 1,63$ & $-3,34$ & 0,001 \\
\hline $\begin{array}{l}\text { Bendras suminis } \\
\text { žinių rodiklis }\end{array}$ & $16,09 \pm 3,90$ & $17,53 \pm 3,38$ & $-3,89$ & $<0,001$ \\
\hline
\end{tabular}


skausmo (S). Gyvenantys su partneriu geriau vertino savo sveikatą (BSV), energingumą (gyvybingumą) (EG), socialinę funkciją (SF) ir emocinę būklę (EB) (2 pav.).

Tiriamujų su sveikata susijusios gyvenimo kokybės vertinimai visose srityse buvo reikšmingai susiję su jų amžiumi ir AH trukme. Vyresnio amžiaus ir ilgiau AH sergantys pacientai su sveikata susijusią gyvenimo kokybę prasčiau vertino visose srityse. Vyresni tiriamieji ir ilgiau sergantys AH buvo mažiau fiziškai aktyvesni, jų veikla labiau ribota dèl fizinių ir emocinių problemu bei skausmo, blogiau vertino savo sveikatą, energingumą (gyvybingumą) ir socialinę funkciją, nei jaunesni ir trumpiau AH sergantys tiriamieji. Emocinę būklę vyresni tiriamieji taip pat vertino prasčiau, nei jaunesni. AH trukmè reikšmingos įtakos neturejjo (3 lentelè). Nustatyti reikšmingi ryšiai tarp KMI ir fizinio aktyvumo, veiklos apribojimo dèl fizinių problemų ir skausmo. Didesnès kūno masès tiriamieji buvo mažiau fiziškai aktyvus, jų veikla labiau ribota dèl fizinių problemų ir skausmo (3 lentelè).

Sergančiųų AH ligos suvokimui, žinioms apie ligą ir su sveikata susi-

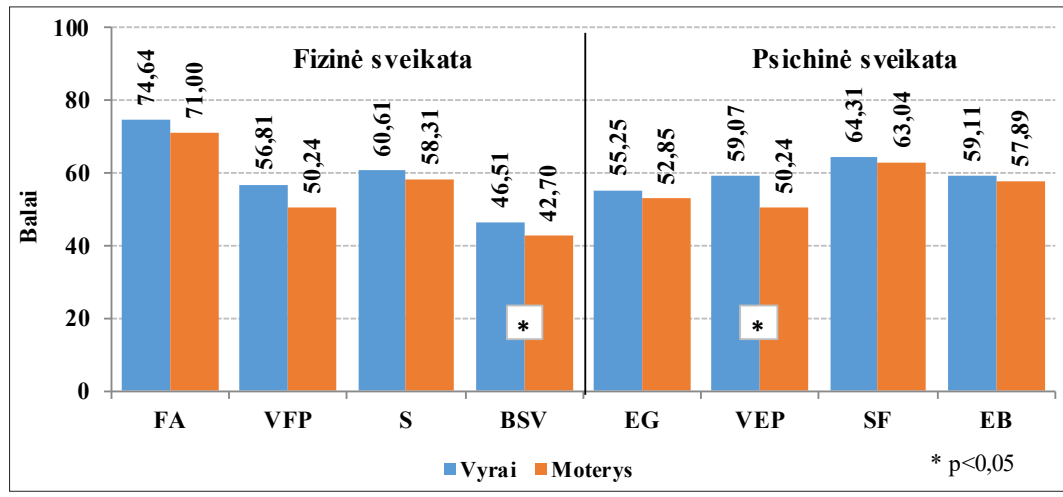

1 pav. Su sveikata susijusios gyvenimo kokybès sričių vertinimai pagal lytị

FA - fizinis aktyvumas, VFP - veiklos apribojimas dèl fiziniu negalavimu, $S$-skausmas, BSV-bendras sveikatos vertinimas, EG - energingumas (gyvybingumas), VEP - veiklos apribojimas dèl emociniu sutrikimu, $S F$ - socialiné funkcija, EB - emociné büklé

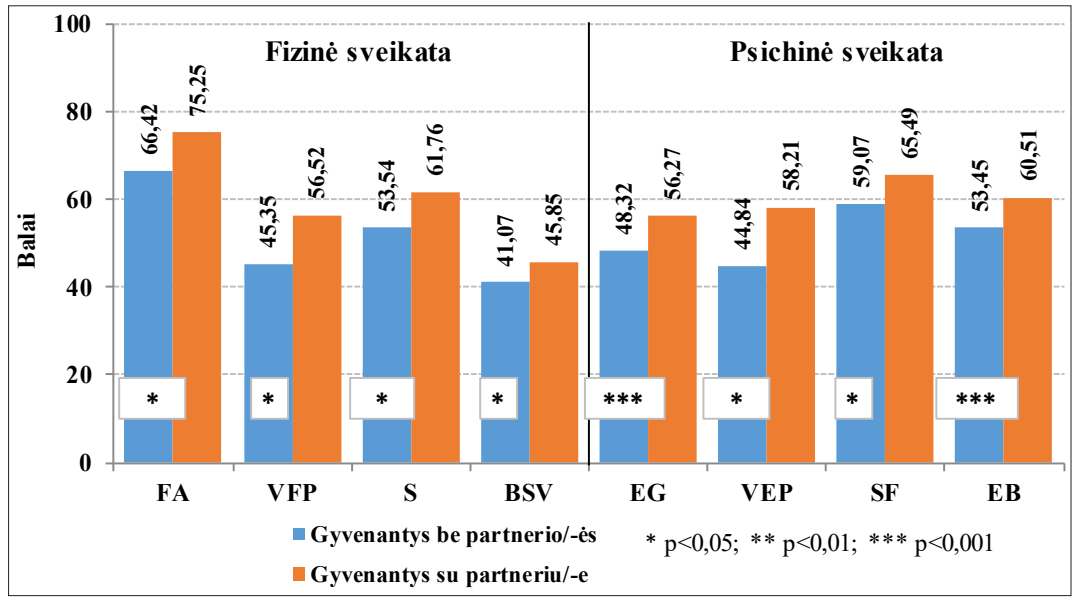

2 pav. Su sveikata susijusios gyvenimo kokybės sričių vertinimas pagal šeiminę padètị FA-fizinis aktyvumas, VFP-veiklos apribojimas dèl fiziniu negalavimu, $S$-skausmas, BSV-bendras sveikatos vertinimas, EG - energingumas (gyvybingumas), VEP - veiklos apribojimas dèl emociniu sutrikimu, $S F$ - socialiné funkcija, EB - emocinè büklè jusiai gyvenimo kokybei įtaką darantys veiksniai. Nustatyti reikšmingi ryšiai tarp AH rizikos sveikatai suvokimo, ligos kontrolès ir bendrujų žinių apie ligą. Turintys daugiau žinių apie AH, geriau suvokè šios ligos keliamą riziką ir jos kontrolę (4 lentelè).

Geresnis ligos rizikos sveikatai suvokimas ir geresnis ligos kontrolès suvokimas susiję su geresnèmis žiniomis apie AH medicinini gydymą, medikamentu vartojimą, komplikacijas, gyvenimo būdą sergant $\mathrm{AH}$ ir žinant AKS ir AH reikšmę, tačiau turintys daugiau žinių apie sergančiųų AH dietą, nepakankamai suvokè ligos kontrolès svarbą. Geresnis ligos keliamų sunkumų suvokimas susijęs su geresnèmis žiniomis apie dietą, gyvenimo būdą sergant $\mathrm{AH}$, medicinini gydymą. Turintys daugiau žinių apie komplikacijas, dažniau nesutiko su ligos keliamais sunkumais (4 lentelè). Didesnis fizinis aktyvumas, mažesnis veiklos apribojimas dèl fizinių problemų ir skausmo susijęs su geresnèmis žiniomis apie AH (5 lentelè).

Geresnès žinios apie AKS ir AH reikšmę, medikamentų vartojimą, gyvenimo būdą ir dietą susijusios su didesniu fiziniu aktyvumu, o geresnès žinios apie AH komplikacijas - su mažesniu veiklos apribojimu dèl fizinių problemų ir skausmo. Geresnès žinios apie medikamentų vartojimą ir apie sergančiųų $\mathrm{AH}$ gyvenimo būdą susijusios su geresniu bendros sveikatos vertinimu (5 lentelè). Didesnis energingumas (gyvybingumas) ir geresnè emocinè būklè susijusi su geresnėmis žiniomis apie AH (6 lentelè).

Geresnès žinios apie komplikacijas susijusios su didesniu energingumu (gyvybingumu), mažesniu veiklos apribojimu dèl emocinių problemų, geresne socialine funkcija ir emocine būkle. Geresnès žinios apie medikamentų vartojimą sergant $\mathrm{AH}$, susijusios su didesniu energingumu (gyvybingumu) ir geresne emocine būkle. Geriau žinantys apie sergančiųjų AH dietą buvo prastesnès emocinès būklès, nei mažiau apie dietą žinantys tiriamieji (6 lentelè). 
3 lentelè. Gyvenimo kokybės sričių sąsajos pagal lytị, kūno masės indeksą ir ligos trukmę

$K M I$ - küno masès indeksas, $r$-taikytas Pearson metodas, $r_{-}$-taikytas Spearman metodas, ns - statistiškai nereikšmingas ryšys

\begin{tabular}{|c|c|c|c|c|c|c|}
\hline \multirow{2}{*}{ Sritys } & \multicolumn{2}{|c|}{ Amžius } & \multicolumn{2}{|c|}{ KMI } & \multicolumn{2}{|c|}{ AH trukmė } \\
\hline & $\mathbf{r}$ & $\mathbf{p}$ & $\mathbf{r}$ & $\mathbf{p}$ & $\mathbf{r}_{\mathrm{s}}$ & $\mathbf{p}$ \\
\hline \multicolumn{7}{|l|}{ Fizinė sveikata } \\
\hline $\begin{array}{l}\text { Fizinis aktyvu- } \\
\text { mas }\end{array}$ & $-0,57$ & $<0,001$ & $-0,15$ & 0,004 & $-0,51$ & $<0,001$ \\
\hline $\begin{array}{l}\text { Veiklos apribo- } \\
\text { jimas dèl fizinių } \\
\text { problemų }\end{array}$ & $-0,55$ & $<0,001$ & $-0,11$ & 0,028 & $-0,39$ & $<0,001$ \\
\hline Skausmas & $-0,47$ & $<0,001$ & $-0,12$ & 0,021 & $-0,35$ & $<0,001$ \\
\hline $\begin{array}{l}\text { Bendras sveikatos } \\
\text { vertinimas }\end{array}$ & $-0,50$ & $<0,001$ & $-0,04$ & ns & $-0,45$ & $<0,001$ \\
\hline \multicolumn{7}{|l|}{ Psichinė sveikata } \\
\hline $\begin{array}{l}\text { Energingumas } \\
\text { (gyvybingumas) }\end{array}$ & $-0,36$ & $<0,001$ & $-0,07$ & ns & $-0,26$ & $<0,001$ \\
\hline $\begin{array}{l}\text { Veiklos apriboji- } \\
\text { mas dėl emocinių } \\
\text { problemų }\end{array}$ & $-0,47$ & $<0,001$ & $-0,04$ & ns & $-0,33$ & $<0,001$ \\
\hline Socialinė funkcija & $-0,44$ & $<0,001$ & $-0,05$ & ns & $-0,35$ & $<0,001$ \\
\hline Emocinè būklè & $-0,16$ & 0,001 & $-0,02$ & ns & $-0,08$ & ns \\
\hline
\end{tabular}

Tyrimo rezultatai parode, kad geresnis ligos suvokimas susijęs su prastesne gyvenimo kokybe. Ligos suvokimo sunkumai turèjo neigiamą ryši su visomis su sveikata susijusios gyvenimo kokybès sritimis $(p<0,001)$. Prasčiau vertinantys savo gyvenimo kokybę geriau suvokè AH keliamus sunkumus, nei tiriamieji, geriau vertinantys savo gyvenimo kokybę. Geresnis ligos rizikos sveikatai suvokimas susijęs su prastesne gyvenimo kokybe. Prastesnès sveikatos, mažesnio fizinio aktyvumo, energingumo (gyvybingumo), prastesnès socialinès funkcijos, labiau apribotos veiklos dèl fiziniu ir emociniu problemų bei skausmo tiriamieji geriau suvokè ligos riziką sveikatai. Geresnis ligos kontrolès suvokimas susijęs su didesniu energingumu (gyvybingumu), geresne socialine funkcija, emocine būkle, mažesniu veiklos apribojimu dẻl fizinių ir emocinių problemų bei skausmo (7 lentelè).

Nustatyta, kad su sveikata susijusiai gyvenimo kokybei įtakos turi lytis, amžius, šeiminè padètis, AH trukmè ir AH keliami sunkumai. Teigiamos itakos turi geresnis ligos kontrolès būtinumo suvokimas. Visose gyvenimo kokybės srityse, susijusiose su
4 lentelè. Žinių apie AH ir ligos suvokimo sąsajos

$r$-taikytas Pearson metodas, $r$-taikytas Spearman metodas, a-taikytas Spearman metodas, ns- statistiškai nereikšmingas ryšys

\begin{tabular}{|l|c|c|c|c|c|c|}
\hline \multirow{2}{*}{ Skalės } & \multicolumn{6}{|c|}{ Ligos suvokimas } \\
\cline { 2 - 7 } & \multicolumn{2}{|c|}{$\begin{array}{c}\text { rizika } \\
\text { sveikatai }\end{array}$} & $\begin{array}{c}\text { keliami sun- } \\
\text { kumai }\end{array}$ & \multicolumn{2}{c|}{ kontrolė } \\
\cline { 2 - 7 } & $\mathbf{r}$ & $\mathbf{p}$ & $\mathbf{r}$ & $\mathbf{p}$ & $\mathbf{r}$ & $\mathbf{p}$ \\
\hline $\begin{array}{l}\text { AKS ir AH } \\
\text { apibrezžimas }\end{array}$ & 0,13 & 0,010 & 0,09 & $\mathrm{~ns}$ & 0,12 & 0,015 \\
\hline $\begin{array}{l}\text { Medicininis } \\
\text { gydymas }\end{array}$ & 0,25 & $<0,001$ & 0,12 & 0,015 & 0,13 & 0,010 \\
\hline $\begin{array}{l}\text { Medikamentų } \\
\text { vartojimas }\end{array}$ & 0,23 & $<0,001$ & 0,03 & $\mathrm{~ns}$ & 0,23 & $<0,001$ \\
\hline $\begin{array}{l}\text { Gyvenimo } \\
\text { būdas }\end{array}$ & 0,14 & 0,007 & 0,14 & 0,008 & 0,16 & 0,002 \\
\hline Dieta & $-0,05$ & $\mathrm{~ns}$ & 0,29 & $<0,001$ & $-0,12$ & 0,019 \\
\hline Komplikacijos & 0,16 & 0,002 & $-0,17$ & 0,001 & 0,19 & $<0,001$ \\
\hline $\begin{array}{l}\text { Bendras } \\
\text { suminis žinių } \\
\text { rodiklis }\end{array}$ & 0,28 & $<0,001$ & 0,03 & $\mathrm{~ns}$ & 0,25 & $<0,001$ \\
\hline
\end{tabular}

5 lentelė. Žinių apie AH ir su fizine sveikata susijusios gyvenimo kokybès sąsajos

a-taikytas Spearman metodas, FA-fizinis aktyvumas, VFP-veiklos apribojimas dèl fiziniu negalavimu, $S$-skausmas; $B S V$ - bendras sveikatos vertinimas, $n s-s t a-$ tistiškai nereikšmingas ryšys

\begin{tabular}{|l|c|c|c|c|c|c|c|c|}
\hline \multirow{2}{*}{ Skalės } & \multicolumn{2}{|c|}{ FA } & \multicolumn{2}{c|}{ VFP } & \multicolumn{2}{c|}{ S } & \multicolumn{2}{c|}{ BSV } \\
\cline { 2 - 10 } & $\mathbf{r}$ & $\mathbf{p}$ & $\mathbf{r}$ & $\mathbf{p}$ & $\mathbf{r}$ & $\mathbf{p}$ & $\mathbf{r}$ & $\mathbf{p}$ \\
\hline AKS ir AH apibrěžimas & 0,19 & $<0,001$ & $-0,02$ & $\mathrm{~ns}$ & 0,07 & $\mathrm{~ns}$ & 0,02 & $\mathrm{~ns}$ \\
\hline Medicininis gydymas & 0,07 & $\mathrm{~ns}$ & 0,04 & $\mathrm{~ns}$ & 0,04 & $\mathrm{~ns}$ & 0,05 & $\mathrm{~ns}$ \\
\hline $\begin{array}{l}\text { Medikamentų vartoji- } \\
\text { mas }\end{array}$ & 0,17 & 0,001 & 0,07 & $\mathrm{~ns}$ & 0,04 & $\mathrm{~ns}$ & 0,11 & 0,031 \\
\hline Gyvenimo būdas & 0,19 & $<0,001$ & 0,05 & $\mathrm{~ns}$ & 0,03 & $\mathrm{~ns}$ & 0,11 & 0,035 \\
\hline Dieta & 0,15 & 0,003 & 0,04 & $\mathrm{~ns}$ & 0,03 & $\mathrm{~ns}$ & 0,00 & $\mathrm{~ns}$ \\
\hline Komplikacijos & 0,06 & $\mathrm{~ns}$ & 0,15 & 0,004 & 0,21 & $<0,001$ & 0,00 & $\mathrm{~ns}$ \\
\hline $\begin{array}{l}\text { Bendras suminis žinių } \\
\text { rodiklis }\end{array}$ & 0,19 & $<0,001$ & 0,11 & 0,024 & 0,14 & 0,007 & 0,08 & $\mathrm{~ns}$ \\
\hline
\end{tabular}

6 lentelè. Žinių apie AH ir su psichine sveikata susijusios gyvenimo kokybès sąsajos a-taikytas Spearman metodas, EG-energingumas (gyvybingumas), VEP-veiklos apribojimas dél emociniu sutrikimu, SF-socialinè funkcija, EB - emocinè büklè, ns - statistiškai nereikšmingas ryšys

\begin{tabular}{|l|c|c|c|c|c|c|c|c|}
\hline \multirow{2}{*}{ Skalės } & \multicolumn{2}{|c|}{ EG } & \multicolumn{2}{c|}{ VEF } & \multicolumn{2}{c|}{ SF } & \multicolumn{2}{c|}{ EB } \\
\cline { 2 - 9 } & $\mathbf{r}$ & $\mathbf{p}$ & $\mathbf{r}$ & $\mathbf{p}$ & $\mathbf{r}$ & $\mathbf{p}$ & $\mathbf{r}$ & $\mathbf{p}$ \\
\hline $\begin{array}{l}\text { AKS ir AH apibrěži- } \\
\text { mas }^{\text {a }}\end{array}$ & 0,07 & $\mathrm{~ns}$ & $-0,09$ & $\mathrm{~ns}$ & $-0,06$ & $\mathrm{~ns}$ & 0,02 & $\mathrm{~ns}$ \\
\hline Medicininis gydymas & 0,04 & $\mathrm{~ns}$ & 0,00 & $\mathrm{~ns}$ & $-0,05$ & $\mathrm{~ns}$ & $-0,03$ & $\mathrm{~ns}$ \\
\hline $\begin{array}{l}\text { Medikamentų varto- } \\
\text { jimas }\end{array}$ & 0,14 & 0,007 & 0,05 & $\mathrm{~ns}$ & 0,04 & $\mathrm{~ns}$ & 0,12 & 0,023 \\
\hline Gyvenimo būdas & $-0,05$ & $\mathrm{~ns}$ & 0,01 & $\mathrm{~ns}$ & $-0,01$ & $\mathrm{~ns}$ & $-0,11$ & 0,026 \\
\hline Dieta & 0,02 & $\mathrm{~ns}$ & 0,02 & $\mathrm{~ns}$ & $-0,10$ & $\mathrm{~ns}$ & $-0,04$ & $\mathrm{~ns}$ \\
\hline Komplikacijos & 0,23 & $<0,001$ & 0,14 & 0,005 & 0,18 & 0,001 & 0,27 & $<0,001$ \\
\hline $\begin{array}{l}\text { Bendras suminis žinių } \\
\text { rodiklis }\end{array}$ & 0,16 & 0,002 & 0,08 & $\mathrm{~ns}$ & 0,05 & $\mathrm{~ns}$ & 0,12 & 0,017 \\
\hline
\end{tabular}


fizine sveikata bei energingumu (gyvybingumu), geresni vertinimai susiję su geresnèmis žiniomis apie AH. Tyrimo rezultatai parodè, kad žinios ir suvokimas apie ligą, skirtingai veikia su sveikata susijusią gyvenimo kokybę. Tiriamieji, turintys daugiau žinių apie ligą, geriau vertino su sveikata susijusią gyvenimo kokybę, o geriau suvokiantys ligą, gyvenimo kokybę vertino blogiau. Turintys daugiau žinių apie ligą, pacientai yra kur kas energingesni, geresnès emocinès būsenos, linkę laikytis mitybos ir fizinio aktyvumo rekomendacijų. Geriau suvokiantys ligą pacientai yra prastesnès sveikatos, mažesnio fizinio aktyvumo ir energingumo, blogesnès emocinès būsenos. Mūsų atliktas tyrimas jungia tris skirtingus aspektus - su sveikata susijusią gyvenimo kokybę, paciento žinias apie AH ir ligos suvokimą.

\section{Išvados}

1. Nustatytas žinių ir ligos suvokimo lygmuo bei jų poveikis su sveikata susijusiai gyvenimo kokybei leidžia pagrịsti pacientų informuotumo, mokymo svarbą bei šios veiklos būtinybę sveikatos priežiūros specialistų darbe.

2. Tiriamieji gerai suvokè arterinès hipertenzijos ligos kontrolę ir riziką sveikatai. Moterys ligos kontrolę vertino geriau, nei vyrai. Vyresnio amžiaus, ilgesnès arterinès hi-

7 lentelè. Ligos suvokimo ir su sveikata susijusios gyvenimo kokybès vertinimų sąsajos

$r$-taikytas Pearson metodas, $r_{s}$ - taikytas Spearman metodas, $n s$ - statistiškai nereikšmingas ryšys

\begin{tabular}{|c|c|c|c|c|c|c|}
\hline \multirow{3}{*}{ Sritys } & \multicolumn{6}{|c|}{ Ligos suvokimas } \\
\hline & \multicolumn{2}{|c|}{$\begin{array}{c}\text { rizika svei- } \\
\text { katai }\end{array}$} & \multicolumn{2}{|c|}{$\begin{array}{l}\text { keliami sun- } \\
\text { kumai }\end{array}$} & \multicolumn{2}{|c|}{ kontrolė } \\
\hline & $\mathbf{r}$ & $\mathbf{p}$ & $\mathbf{r}$ & $\mathbf{p}$ & $\mathbf{r}$ & $\mathbf{p}$ \\
\hline \multicolumn{7}{|l|}{ Fizinė sveikata } \\
\hline $\begin{array}{l}\text { Fizinis aktyvu- } \\
\text { mas }\end{array}$ & $-0,21$ & $<0,001$ & $-0,34$ & $<0,001$ & 0,08 & ns \\
\hline $\begin{array}{l}\text { Veiklos apri- } \\
\text { bojimas dèl fi- } \\
\text { zinių problemų }\end{array}$ & $-0,19$ & $<0,001$ & $-0,45$ & $<0,001$ & 0,11 & 0,039 \\
\hline Skausmas & $-0,15$ & 0,004 & $-0,53$ & $<0,001$ & 0,15 & 0,004 \\
\hline $\begin{array}{l}\text { Bendras svei- } \\
\text { katos vertini- } \\
\text { mas }\end{array}$ & $-0,25$ & $<0,001$ & $-0,39$ & $<0,001$ & 0,08 & ns \\
\hline \multicolumn{7}{|c|}{ Psichinė sveikata } \\
\hline $\begin{array}{l}\text { Energingumas } \\
\text { (gyvybingu- } \\
\text { mas) }\end{array}$ & $-0,17$ & 0,001 & $-0,55$ & $<0,001$ & 0,18 & $<0,001$ \\
\hline $\begin{array}{l}\text { Veiklos apribo- } \\
\text { jimas dėl emo- } \\
\text { cinių problemų }\end{array}$ & $-0,19$ & $<0,001$ & $-0,49$ & $<0,001$ & 0,12 & 0,017 \\
\hline $\begin{array}{l}\text { Socialine funk- } \\
\text { cija }\end{array}$ & $-0,23$ & $<0,001$ & $-0,59$ & $<0,001$ & 0,17 & 0,001 \\
\hline Emocinè būklè & $-0,09$ & ns & $-0,47$ & $<0,001$ & 0,17 & 0,001 \\
\hline
\end{tabular}

pertenzijos trukmès ir didesnès kūno masės tiriamieji geriau suvokè ligos riziką sveikatai. Tiriamujjų amžius ir arterinès hipertenzijos trukmè turejo įtakos ligos keliamų sunkumų vertinimui.

3. Geresnès tiriamujų žinios buvo apie arterinę hipertenziją, arterinio kraujospūdžio reikšmę ir dietą, blogesnès - apie ligos komplikacijas ir medicinini gydymą. Moterų žinios buvo geresnès, nei vyrų. Apie gyvenimo būdą, sergant arterine hipertezija, geriau žinojo trumpiau šia liga sergantys tiriamieji.

4. Su sveikata susijusią gyvenimo kokybę neigiamai veikia ligos keliami sunkumai, teigiamai - geresnis ligos kontrolès būtinumo suvokimas. Su fizine sveikata bei energingumu (gyvybingumu) susijusią gyvenimo kokybę geriau vertino turintieji geresnių žinių apie ligą. Su sveikata susijusią gyvenimo kokybę visose srityse geriau vertino poroje gyvenantys tiriamieji, blogiau - moterys, vyresnio amžiaus ir ilgiau sergantys arterinès hipertenzijos liga.

\section{Literatūra}

1. Blacher J, Halimi JM, Hanon O, Mourad JJ, Pathak A, Schnebert B, Girerd X, French Society of hypertension. Management of hypertension in adults: the 2013 French Society of Hypertension guidelines. Fundamental and Pharmacology 2013;28(1):1-9. https://doi.org/10.1111/fcp.12044

2. Erkoc BS, Isikli B, Metintas S, Kalyoncu C. Hypertension knowledge-level scale (HK-LS): a study on development, validity and reliability. Int J Environ Res Public Health 2012; 9(3):1018-1029.

https://doi.org/10.3390/ijerph9031018

3. Grad I, Mastalerz-Migas A, Kilis-Pstrusinska K. Factors associated with knowledge of hypertension among adolescents: implications for preventive education programs in primary care. BMC Public Health 2015;15:463-471.

https://doi.org/10.1186/s12889-015-1773-7

4. Hultgren J, Jonasson G, Billhult A. From resistance to rescue - patients' shifting attitudes to anthypertensives: a qualitative study. Scandinavian Journal of Primary Health Care 2014;32: 163-169.

https://doi.org/10.3109/02813432.2014.982365

5. Legido-Quigley H, Camacho Lopez PA, Balabanova D, Perel P, Lopez-Jaramillo P, Nieuwlaat R, Schwalm JD. Patients' knowledge, attitudes, behaviour and health care experiences on the prevention, detection, management and control of hypertension in Columbia: a qualitative study. PLOS One, 2015;10(4):1-16. https://doi.org/10.1371/journal.pone.0122112

6. Mikaliūkštienė A., Savickienė V., Kalibatienė D. Arterinès hipertenzijos rizikos veiksnių ir požiūrio ị ligos kontrolę įvertinimas šia liga sergančiu atestuotu pareigūnų grupejje. Medicinos teorija ir praktika, 2013;19(3.2):63-72.

7. Norris CK, Brown AF. The highs and lows of blood pressure 
targets in elderly adults and other high-risk populiations. J Am Geriatr Soc 2015;63(10):2139-2141.

https://doi.org/10.1111/jgs.13699

8. Paulauskienė S, Tutkuvienė J, Šapoka V. Jaunų žmonių prehipertenzija - ar tai pavojinga? Visuomenès sveikata, 2011;1(52):58-64.

9. Peiris D, Thompson SR, Beratarrechea A, Cardenas MK, Diez-Canceso F. Beehaviour change strategies for redusing blood pressure-related disease burden: findings from a global implementation research programme. Implementation Science 2015;10:158-173.

https://doi.org/10.1186/s13012-015-0331-0

10. Simanauskas K. Paauglių pirminès arterinès hipertenzijos sąsajos su fizine ir psichine sveikata bei širdies ir kraujagyslių ligų rizikos veiksniais. Daktaro disertacija. Vilnius: Vilniaus universitetas, 2013.

11. Staniūtė M. Su sveikata susijusios gyvenimo kokybès vertinimas naudojant SF-36 klausimyną. Biologinè psichiatrija ir psichofarmakologija, 2007;9(1):22-25.

12. Šakalytė G, Babarskienė RM, Baronaitè-Dūdonienė K, Karaliūtė R. Lietuvos gydytojų ir pacientų žinios apie arterinę hipertenziją. Visuomenès sveikata, 2013;4(63):47-52.

13. Vaizgutaitė D. Asmenų, sergančių arterine hipertenzija, poreikiai ir lūkesčiai. Medicinos magistro baigiamasis darbas. Kaunas: LSMU, 2016.

14. Zamalijeva O. Sergančiųjų lètinèmis ligomis gydymo nurodymų laikymąsi prognozuojantys veiksniai. Daktaro disertacija. Vilnius: Vilniaus universitetas, 2016.

15. Zavedskaitė J. Sergančiųjų arterine hipertenzija žinių ir savirūpos vertinimas. Magistro studijų baigiamasis darbas. Kaunas: Lietuvos sveikatos mokslų universitetas, 2017.

16. Zyoud SH, Al-Jabi SW, Sweileh WM, Morisky DE. Relationship of treatment satisfaction to medication adherence: findings from a cross-sectional survey among hypertensive patients in Palestine. Health and Quality of Life Outcomes 2013;11:191-198.

https://doi.org/10.1186/1477-7525-11-191

17. Zyoud SH, Al-Jabi SW, Sweilwh WM, Wildali AH, Saleem HM, Aysa HA, Badwan M, Awang R, Morisky DE. Healthrelated quality of life associated with treatment adherence in patients with hypertension: a cross selection study. Int J Cardiol 2013;168:2981-2983.

https://doi.org/10.1016/j.ijcard.2013.04.105

\section{THE RELATED LINKS BETWEEN QUALITY OF LIFE AND PERCEPTION AND KNOWLEDGE OF THE DISEASE IN PATIENTS WITH ARTERIAL HYPERTENSION \\ J. Sąlyga, G. Šakalytė, L. Kazlauskienė, V. Motužytė, G. Žiliukas}

Key words: arterial hypertension, quality of life, perception, knowledge of the disease.

Summary

The aim of this study was to analyze the health - related links between quality of life and perception and knowledge of the disease in patients with arterial hypertension.

The study consisted of 3 questionnaires: "Arterial Hypertension Knowledge Level Scale"; "Perception of Disease Questionnaire"; "Health-Related Quality of Life Questionnaire". There were 389 respondents: 180 men and 209 women. Data analysis was conducted using the statistical software package "SPSS 17.0.1 for Windows". The research was conducted in accordance with ethical principles.

It was found that those who participated in the study were well aware of their disease control and risk. Women's knowledge was noticeably $(\mathrm{p}<0.001)$ better than men's. The results showed that the quality of life is negatively affected by the difficulties caused by the disease, and positively by the perception of the need for better disease control. In all areas of quality of life related to physical health and energy/vitality, better evaluations are associated with better knowledge of arterial hypertension.

Knowledge and perception of the disease have a profound effect on health-related quality of life. Patients with more knowledge about the disease have better assessment of health-related quality of life, and those with less perception of the disease have worse.

Correspondence to: kazlauskiene.laimute@gmail.com

Gauta 2020-11-10 